\title{
"CLIMATE CHANGE AND RECENT SEVERE FLOODING IN UYO, AKWA IBOM STATE, NIGERIA"
}

\section{J. EKPOH}

\begin{abstract}
This paper considered the phenomenon of climate change in relation to frequent and intensified flood problems in Uyo, the Capital City of Akwa Ibom State, Nigeria. Empirical evidence on the onset of climate change in Nigeria was presented. Flood problems worldwide were highlighted, together with their impacts in terms of deaths, economic losses and associated human sufferings. To this end, a detailed rainfall analysis was conducted for the study area, Uyo, using statistical distributions commonly deployed to describe climate states, such as the mean, the running mean, the standard deviation, coefficient of variability, skewness, and kurtosis, as well as, parametric statistics such as Kruskal-Wallis test and ANOVA. Results showed that recent rainfall amounts and patterns in Uyo were out of step with long-term mean conditions. For instance the 2005-2014 mean rainfall was $22 \%$ above the 30-year mean from 1985 to 2014. The rainfall Skewness and Kurtosis showed significant swings in the central tendency and confirmed the establishment of a new mean and a new standard deviation in the 2005-2014 decade. These trends were further confirmed to be statistically significant by Post Hoc Test at the 0.05 level. The implication of these findings is that rainfall is adding more water to surface runoff, leading to incessant, severe flood conditions. Although some effort has been made to reduce the incidence of flooding in Uyo through the provision of drains and storm sewers (pipe-jacking), a lot more needs to be done in terms of provision of infiltration surfaces (green areas) through sustainable urban renewal programme. Climate change mitigation options such as reducing gas flaring, bush burning, and fossil fuel combustion are recommended.
\end{abstract}

KEYWORDS: Climate Change; Flooding; Pipe-Jacking; Green Areas.

\section{INTRODUCTION}

Climate is always changing and will continue to change throughout earth's history. However, the current climate change which started since the late 1960s has occurred at an alarming speed and is attributed largely to human activities. As communities try to improve their living standards, with its concomitant modernization of urban and rural environments through the provision of infrastructures, a pressure is exerted on the earth's resources, especially fossil fuel and forest resources. Carbon dioxide, a major bi-product of fossil fuel consumption and forest clearance have been implicated, alongside other greenhouse gases such as methane, nitrous oxide and chlorofluorocarbon, as being largely responsible for the current global warming.

Fluctuation is an integral part of weather and climate. However, while the fluctuation that characterizes the day-to-day, month-to-month, or even year-to-year variations around the mean-state may be seen as normal, the fluctuation in climate which seeks to change the long-term mean and standard deviation (i.e., a change in the central tendency) of the climate of a place is an abnormal situation and is referred to as climate change. Thus, climate change has been defined as a shift in the long-term mean values of a climatic parameter or statistic, where the mean is taken on a specified interval of time scales varying from a number of decades; say thirty years to millions of years (Parry, 1995; Adejuwon, 2012; Ayoade, 2004; Ekpoh, 2009). Much of the apprehension that surrounded the onset of climate change in the 1980s and 1990s have largely been resolved through the efforts of the Intergovernmental Panel on Climate Change (IPCC). Today it is no

I. J. Ekpoh, Department of Geography and Natural Resources Management, University of Uyo, Uyo. Nigeria 
longer news that the earth's atmosphere is warming due largely to human activities, namely, primarily fossil fuel combustion, industrial processes and deforestation, which causes the release of greenhouse gases such as carbon dioxide, methane, nitrous oxide and chlorofluorocarbons into the atmosphere. From a pre-industrial level of 280 parts per million by volume (ppmv), carbon dioxide, for instance, had increased to 380 ppmv by 2005; an increase of about 40 per cent. Indeed, the 2015 level of carbon dioxide in the atmosphere is put at 400 ppmv. The preponderance of greenhouse gases in the earth's atmosphere is responsible for the formation of a gas layer in the troposphere called the greenhouse gas layer. It is this gas layer which has caused global warming of the earth's atmosphere, by allowing short-wave solar radiation to pass through it to the earth's surface while restricting the spaceward journey of some of the long-wave terrestrial radiation, thus causing a surplus heat budget in the lower atmosphere. Global warming has already resulted in an increase in the global mean temperature of the atmosphere by about $0.6^{\circ} \mathrm{C}$, and a continuation of the historical trend of greenhouse gas emissions under the "businessas-usual" scenario of human activity will lead to a further rise in air temperature throughout the $21^{\text {st }}$ century (IPCC, 2007). Already, current predictions from General Circulation Models (GCMs) suggest a global temperature rise of between $1.1^{\circ} \mathrm{C}$ and $6.4^{\circ} \mathrm{C}$ by 2100 . Rising atmospheric temperatures mean more energy for evaporation and evapotranspiration processes. Enhanced and intensified evaporation also translate to increased rainfall in many regions. As predicted by IPCC (2007) Report, southern parts of Nigeria will experience more rainfall leading to severe flooding, while the northern parts of Nigeria will witness more droughts and water shortages.

Recent severe flooding worldwide have attracted the attention, not only of the scientific community, but also governments, nongovernmental agencies and the general public, largely due to the enormous human sufferings and hardships associated with them. A cursory examination of long-term rainfall data for Uyo shows that flooding used to occur in cycles of 20 to 30 years, with sufficient time-span for recovery. However, since the late 1960s, flooding in Uyo has become a near, yearly ritual, with little or no time for recovery. This is probably why the impacts of contemporary back-to-back flood episodes are so severe. Any effort at understanding the modus operandi of recurrent incessant floods in Uyo and other coastal cities in Nigeria should be a welcomed development.

\section{Emperical evidence of Climate Change in Nigeria}

Rainfall is highly variable over a variety of time and space scales and large areas of the earth experience wide variability as part of a "normal" climate. However, largely due to the current climate change, rainfall in many places have shown distributions that are far from the expected or normal. Several studies have shown that Nigeria is already in the thick of climate change (Ekpoh \& Nsa, 2011; Odjugo, 2009; Chindo \& Nyelong, 2004; Mshelia, 2005; Adefolalu, 2007; Esiobu \& Onubuogu, 2014). In a study that involved 30 meteorological stations and 105 years of observation, Odjugo (2010) carried out long-term temperature analysis and the result showed that the mean temperature for Nigeria since 1901 remained steady until the late 1960s when it started a gradual rise that has continued to the present time, in response to global warming. The experiment was repeated for rainfall in Nigeria from 1901 to 2005 and the result showed a general decline, with a loss of $81 \mathrm{~mm}$ of rainfall during the period.

Another study also showed that rainfall in Sokoto for the period from 1968 to 2008 declined by 8.8 percent of the long-term (19152008) mean, while other rainfall characteristics such as late onset, early cessation and long breaks within the rainy season were noticed to have become more frequent (Ekpoh \& Nsa, 2011). A further scrutiny of instrumental data for the country also revealed that climate change impact on rainfall in Nigeria does not translate to a general decline in total amount for all regions but could be quite erratic in amount and pattern of distribution from area to area. It is this erratic nature of climate change that poses the greatest problem to planning and adaptation. As Adefolalu (2007) observed, Nigeria's locational factor (i.e. Nigeria lies between latitudes $4^{\circ} \mathrm{N}$ and $14^{\circ} \mathrm{N}$; and longitudes $2^{0} \mathrm{E}$ and $14^{\circ} \mathrm{E}$ ) suggests perennial humid conditions in the southern states with annual rainfall of $1000 \mathrm{~mm}$ $-2500 \mathrm{~mm}$ but exceeding $3000 \mathrm{~mm}$ in parts of the Niger Delta and the southeast corner, while the extreme drought-prone parts range from $250 \mathrm{~mm}$ to $700 \mathrm{~mm}$. Superimposed on this spatial diversity are the inter- and intra-seasonal variations which are common due to regular transient atmospheric flow patterns and systems and are responsible for localized and regional variations exceeding 50 percent. For instance, many coastal locations in Nigeria such as 
Lagos, Ibadan, Uyo and Calabar have received excessive rainfalls recently which resulted in historic floods that caused substantial loss of lives and property, while locations in northern Nigeria had deficit rainfall budget. (Ekpoh, 2014b; Odjugo, 2010; Baudi \& Ahmed, 2006). Thus, Nigeria is considered to be one of the most climatologically vulnerable countries in Sub-Saharan Africa with respect to climate change.

A study conducted by Abaje, Ati and Iguisi (2012) on annual rainfall trends and fluctuations in Sudano-Sahelian Ecological Zone of Nigeria, which involved eight meteorological stations, with rainfall data from 1949 to 2008, used the Cramer's test compare means. The result of the study revealed that there was a change towards wetter conditions in the last 30 years. Other studies also show that the number of rainy days during the last 30 years have dropped by 53 percent in north-eastern parts of Nigeria while the coastal areas have experienced a drop of about 14 percent in the number of rainy days. Furthermore, the areas experiencing double rainfall maxima have shifted southwards while the short dry season called "August Break" is being experienced more in July as against the usual occurrence in August prior to 1969 (Odjugo, 2010; Ekpoh 2009). While the desiccation which started in the Sahel of West Africa in the late 1960s is implicated as being responsible for the recession of Lake Chad from $25,000 \mathrm{~km}^{2}$ in 1963 to $1,250 \mathrm{~km}^{2}$ in recent times, indicating a loss of about 90 percent of its previous size (Ekpoh \& Nsa, 2011; Odjugo, 2009; Bomford, 2006; Chindo \& Nyelong, 2004). These paradoxes clearly confirm the uncertain and highly unpredictable nature of the anthropogenetically-induced $21^{\text {st }}$ Century climate change. Floods in southern Nigeria used to have rhythms of 25 to 30 years cycle. However, since the late 1960s which signaled the beginning of significant climatic disturbances in sub-Saharan Africa, the recurrence of floods has become irregular with no predictable cycle. From these observations, it sounds reasonable to assume that climate change is already altering the climate of Nigeria substantially.

\section{Physical impacts of Climate Change worldwide}

In recent times, the increased frequency and intensification of climate-related hazards such as thunderstorms, floods, droughts, hurricanes, and tornadoes have been blamed on climate change. These climate changeinduced hazards have adversely affected the lives of millions of people around the world. In the United States for instance, the historic Mississippi river floods of April/May 2011 (the likes of which has not been seen since 1937) caused havoc on farmlands; the 2010 Pakistani floods which directly affected 20 million people through the destruction of property, livelihood and infrastructure, as well as, killing about 2,000 people; the 2013 floods in the Philippines, which was considered the worst in 50 years, left 80 percent of the city of Manila under water, leading to the death of dozens of people, with thousands more displaced (TIME, Sept 2013; The Telegraph, August 2013).

Elsewhere, historic floods have ravaged many parts of the world including several towns and communities in Nigeria. The 2010 Sokoto floods which washed away 20 villages, displaced 130,000 people, killed 6 persons, destroyed the Goronyo Dam, devastated farmlands, collapsed the major bridge linking Usumanu Danfodio University to Sokoto town; the July 10, 2011 extreme rainfall in Lagos which saw non-stop downpour for 14 hours that produced $231 \mathrm{~mm}$ of rainfall; the 2011 floods in Lagos, Ibadan and Calabar that destroyed properties, killed and rendered many people homeless. The 2012 floods in Nigeria which was caused by a combination of unusually heavy rainfall in the Guinea Coastal areas and the release of water from the Lagdo dam in northern Cameroon affected Makurdi, Lokoja, Yenogoa, and so on remains a watershed in the history of flood impacts in Nigeria because the flood affected 7.7 million people, killed 363 persons and displaced 2.1 million (Nation Newspaper, 20 July, 2012). In Uyo, the Akwa lbom State capital, the 2012 floods caused barner headlines such as; "Pipe-Jacking System and the Ravaging Flood menace in Uyo" (RADAR, Vol.2, No.14, Thursday June 26 - Sunday, June 29, 2014) The general outlook for 2013 on the menace of flooding in Nigeria was equally depressing as reported by some Nigerian Dailies. For instance, THISDAY Newspaper of 1 June, 2013 reported that 31 out of 36 States in Nigeria were to experience devastating floods in 2013, going by the prediction from Nigerian Meteorological Agency (NIMET)".

This year, 2015, floods have already caused so much havoc in many parts of the world including North East Japan and the city of Osaki where buildings were seen floating in water like boats. In Nigeria, authorities in northeastern Adamawa state confirmed that already, 30 people have been killed, 120, 000 displaced and farmers were being sacked from their farms. The 2015 flood season in Uyo was not better than earlier episodes. More rainfall fell and the $27^{\text {th }}$ August 2015 rainfall in Uyo produced widespread flood menace which 
prompted such banner headlines as "Flood takes Over Major Roads in Uyo Despite Multimillion Dollar drainage" (Nairaland Forum, 13 September 2015). Areas worst hit by the flood incident included Abak Road by Nkemba street; Oron Road by Uruan Street; IBB Way by Ukpong Ebet and Akpa Ebet Streets; Brooks Street by Gibbs Street; Middle of Nsentip Street; Udo Eduok Street; Ikot Ekpene Road, near former AKTC; Ibom Plaza; Mbiabong Estate, Shelter Afrique, and numerous others. These events indicate the alarming rate at which our climate is changing and thus indicate the urgent need for action.

\section{The Study Area}

Akwa Ibom State, with Uyo as its capital city is located between Latitudes $4^{\circ} 32^{\prime}$ and $7^{\circ}$ $31^{\prime}$ North, and Longitudes $7^{\circ} 25^{\prime}$ and $8^{\circ} 25^{\prime}$ East. The state is bounded on the North by Abia State; on the East by Cross River, on the West by Abia and Rivers States; and on the South by the Atlantic Ocean. Akwa lbom State was carved out of Cross River State to become a full-fledged state of its own on September 23, 1987.

The geology of Akwa lbom State is dominantly that of the coastal plain sands of Tertiary origin, with crystalline rocks of the Basement Complex outcropping in the north and north-eastern flanks of the state. There are pockets of sandstone and shale in Itu-lbiono Ibom-Ini axis of the state. Recent alluvium of the current Quaternary are also found along the banks of the Cross River and Qua lboe River, as well as, along the southern coastal margins that border the Atlantic Ocean. The climate is typically that of the humid tropics with rainfall in all months of the year. The state enjoys two distinct seasons, the wet and the dry, with the longer duration in favour of the wet season. The rainfall pattern exhibits double maxima, with the 'little dry season' in August, popularly called "August Break". Temperature is relatively stable with day temperatures fluctuating between $27^{\circ} \mathrm{C}$ and $33^{\circ} \mathrm{C}$, while night temperatures seldom fall below $15^{\circ} \mathrm{C}$. Humidity is high $(>80 \%)$ and cloud cover is prevalent, especially during the rainy season. The vegetation is a mixture of mangrove swamp forests, fresh water swamp forests, rainforest, palm bushes and secondary forests of fallow bushes and farmlands.

Uyo, the capital city is located in the central part of Akwa Ibom State and can be said to be a rapidly developing urban centre with all the paraphernalia of concrete structures, asphalt surfaces and corrugated iron and aluminum roofs. Being an ancient city, modernization and urban renewal efforts have not been without difficulties, especially with regard to drainage reconstruction. These urban features, together with the characteristic terrain feature of an imperceptibly gently-rolling-landscape, shallow and inadequate surface drains, as well as, the poor attitude of some residents towards waste disposal, have combined to make the city vulnerable to flash flooding whenever it rains.

\section{METHODS AND MATERIALS}

The method adopted for this study was the statistical approach. A station analysis was conducted for rainfall data in Uyo with the aim of establishing the trends and patterns of variability in recent rainfall receipts. Data for the study consisted of annual rainfall figures for 30 years, from 1985 to 2014. The data were obtained from the Meteorological Station at the University of Uyo, Uyo, Nigeria.

To establish the degree of normality or otherwise in the pattern and distribution of rainfall in the last 30 years in Uyo, the data were broken into three decades, 1985-1994, 19952004, 2005-2014. The 30-year long-term data, together with the three decadal groups were analyzed using test statistic such as the mean, the running mean, the standard deviation, the coefficient of variability, the Standard Coefficient of Skewness $\left(Z_{1}\right)$ and the Standard Coefficient of Kurtosis $\left(Z_{2}\right)$. To confirm the patterns, the data were further subjected to parametric statistics such as the Analysis of Variance (ANOVA) and the Kruskal Wallis Test.

In rainfall analysis, the Mean $(\mathrm{X})$, which represents the overall expectation of rainfall or "normal" rainfall, usually provides a crude guide to the characteristics of a locations overall precipitation regime. Also, the statistical validity and usefulness of the mean are often dependent upon the spread of individual amounts about the mean (Sumner, 1988). The mean is given by the formula:

$$
\mu=\sum x P(x)
$$

The Standard Deviation describes the dispersion of rainfall about the mean. A major drawback in using the standard deviation in rainfall analysis is that it is an absolute measure of dispersion, thus of limited value when comparing rainfall data for different groups. The standard deviation is given by the formula:

$$
\sigma=\sqrt{\frac{1}{N}} \sum_{i=1}^{N}\left(x_{i}-\mu\right)^{2}, \text { where } \mu=\frac{1}{N} \sum_{i=1}^{N} x_{i} .
$$

If, instead of having equal probabilities, 
the values have different probabilities, let $x_{1}$ have probability $p_{1}, x_{2}$ have probability $p_{2}, \ldots, x_{N}$ have probability $p_{N}$. In this case, the standard deviation will be

$$
\sigma=\sqrt{\sum_{i=1}^{N} p_{i}\left(x_{i}-\mu\right)^{2}}, \text { where } \mu=\sum_{i=1}^{N} p_{i} x_{j}
$$

An index which measures the relative dispersion of a distribution is the Coefficient of Variation (CV). It is defined as the ratio of the standard deviation $(\sigma)$ to the mean $(\mu)$ :

$$
c_{v}=\frac{\sigma}{\mu}
$$

A critical task in many statistical analyses is to characterize the trend and variability of the data set. Skewness and Kurtosis are measures of symmetry in a data set. In specific terms, however, skewness measures more precisely the dispersion about the central tendency,

The formula for Skewness is given as:

$$
g 1=\sum N i=1(Y i-Y) 3 / N s 3
$$

where $Y$ is the mean, $\boldsymbol{s}$ is the standard deviation, and $N$ is the number of data points. Note that in computing the skewness, the $s$ is computed with $N$ in the denominator rather than $N-1$. The formula for skewness is referred to as the Fisher-Pearson coefficient of skewness.

Kurtosis measures the peakness or otherwise of the data set relative to a normal distribution. For univariate data $Y_{1}, Y_{2}, \ldots, Y_{N}$, the formula for Kurtosis is:

$$
\text { Kurtosis }=\sum N i=1(Y i-Y) 4 / N s 4
$$

where $Y$ is the mean, $\boldsymbol{s}$ is the standard deviation, and $N$ is the number of data points. Note that in computing the kurtosis, the standard deviation is computed using $N$ in the denominator rather than $N-1$.

The Kruskal-Wallis test is a rank-based non-parametric statistic that is often used to determine if there are statistically significant differences between two or more groups of an independent variable. In the present study, the variable was the 30 years rainfall data for Uyo which was broken into decades or groups.

Kruskal-Wallis test statistic is defined as:

$$
H=\frac{12}{n(n \mid 1)} \sum_{j=1}^{k} \frac{R_{j}^{2}}{n_{j}}-3(n+1)
$$

where $k=$ the number of groups, $n_{j}$ is the size of the fth group, $R_{j}$ is the rank sum for the jth group and $n$ is the total sample size, i.e.

$$
n=\sum_{j=1}^{k} n_{j}
$$

Analysis of Variance (ANOVA) is a statistical model used to analyze the differences among group means and their associated procedures, such as "variation" among and between groups. In an experiment with ANOVA, the observed variance in a particular variable is partitioned into components attributable to different sources of variation. Anova assumes that, the null hypothesis $\mathrm{Ho}:{ }_{1}=2=3=4$. This means that there is no difference in the means of the three decades.

In summary, the non-parametric and parametric statistics for this study were performed using the computer-based EXCEL spreadsheet and the SPSS statistical package respectively. The results of the analyses are presented in Tables $1-5$.

\section{RESULTS}

The results of the Station rainfall analysis using the Mean, the Standard Deviation, the Coefficient of Variation, KruskalWallis Test and Analysis of Variance (ANOVA) are presented in Tables $1-5$.

Table 1: Station Rainfall Analysis for Uyo using 30-year data and decadal values

\begin{tabular}{|l|l|l|l|l|l|}
\hline Decade & Mean & $\begin{array}{l}\text { Standard } \\
\text { Deviation }\end{array}$ & $\begin{array}{l}\text { Coefficient of } \\
\text { Variability }\end{array}$ & Skewness & Kurtosis \\
\hline $1985-1994$ & 2243.23 & 232.77 & 10.38 & 0.74 & 0.29 \\
\hline $1995-2004$ & 2195.32 & 305.92 & 13.93 & 1.76 & 3.99 \\
\hline $2005-2014$ & 3042.17 & 493.35 & 16.22 & -0.89 & 2.59 \\
\hline $\begin{array}{l}1985-2014 \\
\text { Long-term }\end{array}$ & 2493.57 & 526.75 & 21.12 & 0.85 & -0.19 \\
\hline
\end{tabular}


Table 2: Kruskal Wallis Test Results: Ranks

\begin{tabular}{|rc|r|r|}
\hline & Decade_1 & N & Mean Rank \\
\hline Rainfall_1 & 1.00 & 10 & 12.30 \\
& 2.00 & 10 & 10.70 \\
& 3.00 & 10 & 23.50 \\
& Total & 30 & \\
\hline
\end{tabular}

Table 3: Kruskal Wallis Test Results: Level of significance

\begin{tabular}{|c|r|}
\hline & Rainfall_1 \\
\hline Chi-Square & 12.552 \\
Df & 2 \\
Asymp. & .002 \\
Sig. & \\
\hline
\end{tabular}

Table 4: Analysis of Variance (ANOVA) Result

\begin{tabular}{|c|c|c|c|c|c|}
\hline & $\begin{array}{l}\text { Sum of } \\
\text { Squares }\end{array}$ & Df & $\begin{array}{l}\text { Mean } \\
\text { Square }\end{array}$ & $F$ & Sig. \\
\hline Between & $\begin{array}{r}4525851 . \\
381 .\end{array}$ & 2 & 2262925.690 & 17.355 & .000 \\
\hline & $\begin{array}{r}3520551 . \\
958\end{array}$ & 27 & 130390.813 & & \\
\hline Total & $\begin{array}{r}8046403 . \\
339\end{array}$ & 29 & & & \\
\hline
\end{tabular}

Table 5: Post Hoc Test Result Dependent Variable: Rainfall_1Scheffe

\begin{tabular}{|c|c|c|c|c|c|c|}
\hline $\begin{array}{l}\text { (I) } \\
\text { Decade_1 }\end{array}$ & $\begin{array}{c}(\mathrm{J}) \\
\text { Decade_1 }\end{array}$ & $\begin{array}{c}\text { Mean } \\
\text { Difference } \\
(I-J)\end{array}$ & Std. Error & Sig. & \multicolumn{2}{|c|}{$95 \%$ Confidence Interval } \\
\hline & & $\begin{array}{l}\text { Lower } \\
\text { Bound }\end{array}$ & $\begin{array}{l}\text { Upper } \\
\text { Bound }\end{array}$ & Lower & $\begin{array}{l}\text { Upper } \\
\text { Bound }\end{array}$ & $\begin{array}{l}\text { Lower } \\
\text { Bound }\end{array}$ \\
\hline \multirow[t]{2}{*}{1.00} & 2.00 & 47.91000 & $\begin{array}{r}161.4873 \\
5\end{array}$ & .957 & -370.3473 & 466.1673 \\
\hline & 3.00 & $\begin{array}{r}798.94000( \\
*\end{array}$ & $\begin{array}{r}161.4873 \\
5\end{array}$ & .000 & $\begin{array}{r}\text { Bound - } \\
1217.1973\end{array}$ & -380.6827 \\
\hline \multirow[t]{2}{*}{2.00} & 1.00 & -47.91000 & $\begin{array}{r}161.4873 \\
5\end{array}$ & .957 & -466.1673 & 370.3473 \\
\hline & 3.00 & 846.85000( & $\begin{array}{r}161.4873 \\
5\end{array}$ & .000 & -1265.1073 & -428.5927 \\
\hline \multirow[t]{2}{*}{3.00} & 1.00 & $\begin{array}{r}798.94000( \\
*)\end{array}$ & $\begin{array}{r}161.4873 \\
5\end{array}$ & .000 & 380.6827 & 1217.1973 \\
\hline & 2.00 & $\begin{array}{r}846.85000( \\
*\end{array}$ & $\begin{array}{r}161.4873 \\
5\end{array}$ & .000 & 428.5927 & 1265.1073 \\
\hline
\end{tabular}

The mean difference is significant at the .05 level. 


\section{DISCUSSION OF RESULTS}

The station-rainfall-analysis performed for Uyo, Akwa lbom State, using a 30-year data from 1985 to 2014 and decadal values for three decades, shows that the mean annual rainfall receipt during the 2005-2014 decade was 22 percent above the 30-year mean (Table 1).

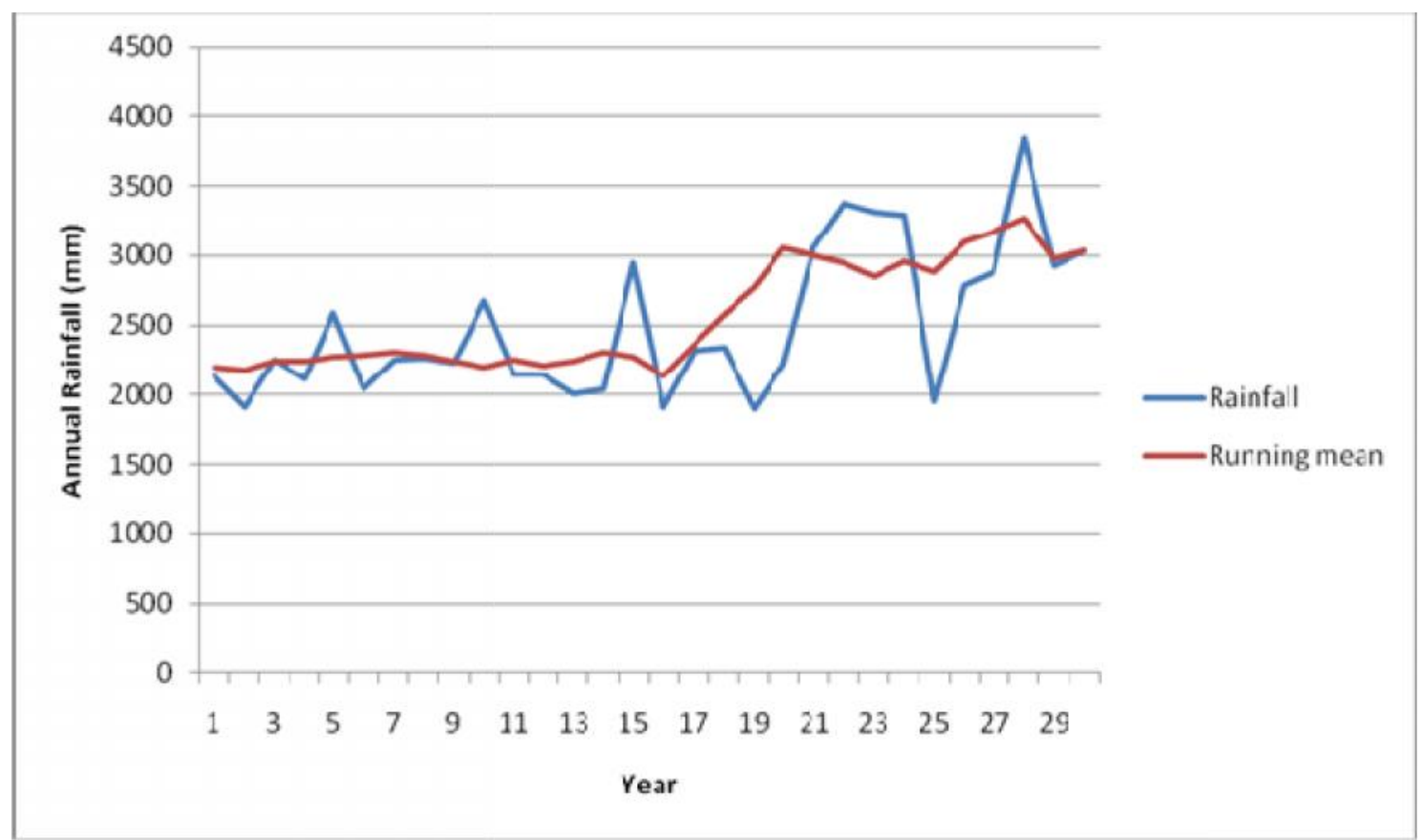

Fig. 1: Annual Rainfall and 5-Year Running Mean for Uyo, Akwa Ibom State (1985-2014)

From Table 1, the 30-year mean rainfall from 1985 to 2014 was $2493.57 \mathrm{~mm}$ (approximately $2500 \mathrm{~mm}$ ). The mean rainfalls for the first two decades of the study were $2243.23 \mathrm{~mm}$ and $2195.32 \mathrm{~mm}$, indicating a drop of $10.04 \%$ and $11.96 \%$ from the 30 -year mean respectively. However, the third decade mean was $3042.17 \mathrm{~mm}$, which showed a $22 \%$ increase in rainfall over the 30 -year mean. The standard deviation and the coefficient of variation also varied substantially between the first two decades and the third decade (Table 1). Also, a close examination of Fig. 1 shows that annual rainfall in Uyo maintained a steady pattern during the first twenty years of the study from 1985 to 2004 . However, during the last decade of the study from 2005 to 2014, the rainfall pattern shifted abruptly over the $3000 \mathrm{~mm}$ mark and has virtually remained in that region since then, except for 2009 when it dropped below the $3000 \mathrm{~mm}$ mark. In the same vein, a 5-year running mean for the climate period 1985-2014 showed that the running mean shifted from an average of about $2200 \mathrm{~mm}$ to a new mean of $3000 \mathrm{~mm}$ (Fig. 1). The 5-year running mean (red line) presented a more graphic picture of the shift as the trend showed a firm pattern from
1985 up to 1998 when the trend experienced a steady rise to a peak in 2004, and a further climb to a climax in 2012. The implication of the emerging rainfall pattern for Uyo is that, the rainfall has established a new mean around $3000 \mathrm{~mm}$ during the last 10 years as against the long-term mean of $2500 \mathrm{~mm}$ (Table 1). These are frightening alterations in the rainfall characteristics of Uyo, whose trend and pattern were further confirmed to be statistically significant with the computation of the KruskalWallis Test and ANOVA (Tables 2-5). Besides these shifts, individual extreme rainfall events have become very common in recent years. For instance, the University of Uyo Meteorological Station recorded a $171.7 \mathrm{~mm}$ rainfall on August 27, 2015, which created flood chaos in Uyo. The extreme rainfall was more than half of the expected mean monthly rainfall of $300 \mathrm{~mm}$ for August in Uyo.

\section{Perspective on Uyo Floods}

Flood is an environmental problem that causes severe hardship to people and economies in the affected area. Uyo, with a land area of $115 \mathrm{~km}^{2}$ (44 sq mi) and a population of 
over half a million (2015 estimate), has experienced flooding in recent times despite serious efforts by successive state and federal governments to address the issue. The near intractable nature of the problem may be due to factors such as topography, massive urbanization, inappropriate drainage network and climate change. With over 90 percent of the land area of Uyo Capital city being gently rolling or flat, the terrain constitutes a serious hindrance to the evacuation of runoff through surface drains. Thus, topography plays a very significant role in making the problem of flooding in Uyo intractable because water has little or nowhere to run to, whenever it rains. In many places, the surface drains or gutters simply serve as mere ditches for runoff to accumulate rather than channels for evacuating runoff, due to the absence of slope. A case in point is the gutter along Abak Road, where stagnant water remains indefinitely with the consequent dangers of mosquitoes breeding in them, together with serious environmental pollution. Some of the gutters were constructed during pre-state creation era when Uyo was just an administrative headquarter with few urban structures and currently unable to withstand the $21^{\text {st }}$ Century climate change-induced rainfall of recent past and present. Massive urbanization in Uyo since it became a state capital in 1987 has not helped matters either, as previously green areas and marginal lands have been seriously encroached upon. Surface drainage systems to check flooding in Uyo do not work due to constraints posed by topography and urbanization. Topography affects surface drainage through the absence of slope while massive and, at times, uncontrolled urbanization constitutes serious obstacle to drainage paths (Ekpoh, 2014a; Adomi and Edem, 2015).

Climate change as a recent phenomenon, has added an unexpected dimension to an already precarious situation of recurrent flooding in Uyo, by bringing more rainfall to coastal and immediate hinterland towns in Nigeria. This has caused serious distortions to the hydro-climatic regime of the study area. As noted earlier, climatic predictions from General Circulation Models (GCMs) for Nigeria suggest that climate change will affect the country through sea level rise along its coastline as well as alterations in the local climate which may witness more extreme rainfall in the south (leading to severe cases of flooding, erosion and mass wasting) and intensified aridity in the north (causing incessant droughts and desertification). These projections are consistent with current, real-time weather observations in Nigeria (Adesina and Odekunle,
2011; Odjugo, 2010; Ekpoh and Nsa, 2011; Ward, 2009).

In addition to the major factors that are responsible for flood problems in Uyo, the habit of disposing wastes into gutters and drains, which is common among residents of the capital city is inimical to effective flood-water evacuation, as the wastes would normally block and glug the gutters, leading to overflow of water from the gutters into streets and homes. Being a humid tropical location, gutters and other open drains in Uyo are vulnerable to siltation from sand, silt and clay fractions, which are products of deeply, chemically weathered regolith. Unauthorized urban structures also obstruct natural water-ways, leading to flooding.

\section{The Way Forward}

"Pipe Jacking" flood control system holds the key to solving flood problems in Uyo. Pipe jacking is a technique for installing underground pipelines, ducts and culverts to evacuate storm waters. Already, the system has been implemented in parts of Uyo capital city, around Itam market and it has proven to be very efficient in evacuating flood-waters. Thus, Pipe Jacking system has the ability to overcome the problem of flat terrain with absence of slope. Although the pipe-jacking system may be expensive, it is a worthwhile effort as it is efficient not only in evacuating runoff through underground tunneling, but also causes minor disruption to the city's infrastructure and facilities as opposed to open drains. Moreover, since pipe-jacking is an underground drainage system, it is also capable of eliminating the problem of silting and wastes disposal into open gutters by the residents. Even at that, stiff penalties should be meted out to culprits who dispose refuse in gutters. More green areas should be created within the city to encourage infiltration of rain water and through-flow. To decongest the present urban crowdedness, new investments and structures should be taken to the urban peripheries of Uyo, as was done with the Ibom Meridien Hotel in Nwangaiba. Also, those structures and facilities that are located on natural drainage channels should be relocated.

Results from this study have clearly implicated climate change as a major factor in the recent flood episodes in Uyo. Therefore, responding to climate change from both policy level and house-hold level is required. At the policy level, climate change mitigation and adaptation require strategic planning through sound policy formulation, provision of regulatory and institutional frameworks, as well as, the building of robust human and material 
capacities. Nigeria has many policies, strategies and plans that are intended to address general adaptation measures in many climate change vulnerable sectors such as agriculture, water resources, health, energy, transportation, forests and ecosystems, and coastal marine environment. However, the policy framework to align human development and climate change efforts through adaptation remain largely undeveloped in the country. Thus, in times of adversity such as severe flooding or back-toback drought, Nigeria has often resorted to "fire brigade" approach of making ad hoc plans to respond to each environmental disaster as they occur. Thereafter, the entire crisis is swept under the carpet without attending to the underlying factors that might have caused the problem in the first instance, and there is no concerted effort to prevent a reoccurrence. The serious concern about this approach of emergency response is that it keeps the impacted community in perpetual cycle of fear, misery and poverty, while making the government to look insensitive and incompetent (Ekpoh, 2014b). Policy responses to the 2010 , 2011 and 2012 flood disasters in Nigeria are clear pointers to the inefficiency of emergency response systems. It would therefore be appropriate if a robust, efficient system of response that would cater not only for the relief materials needed by the people, but also provide the strategy for tackling the underlying causes of the problem through the creation of a systematic framework of doing things. A proper strategy for combating those floods would not only focus on the provision of relief materials, but will also consider the drainage system in terms of apparent need for de-silting of gutters, possible expansion of existing gutters and the construction of new ones (including pipejacking) where necessary, so as to prepare for the containment of future storm-water runoff.

Tackling climate change should be everyone's business and not left for government alone. As a developing nation with abundant natural resources, Nigeria can sustainably manage her forests such that present and future benefits are continually derived. Massive tree planting programs throughout the country and, especially in areas of the country that have already been degraded, should be undertaken. Also, it is necessary to take appropriate steps to end other production processes such as gas flaring in the Niger Delta region towards mitigating climate change. Daily energy conservation measures such as turning off electric lights and appliances when not in use, preferring to walk or cycle rather than driving always, planting trees and creating lawns in our surroundings, should be encouraged at levels such as house-hold and individual.

\section{CONCLUSION}

The study has shown that climate change is one of the major factors responsible for recent, severe flooding in Uyo. Therefore, addressing the problem of urban flooding in Uyo will require a comprehensive response to the issue of climate change. This entails a fundamental shift from the environmental complacent attitude to embracing environmentally sensitive ways that will dramatically reduce emissions of carbon dioxide and other greenhouse gases. In this way, the security of lives, the Nigerian economy and environment will be safeguarded against the adverse effects of climate change, and will guarantee a better and secure future for generations yet unborn. The increasing frequency of climate change-related disasters in Nigeria, especially floods, demand that appropriate plans be made to contain the menace. There is no doubt that some efforts has been made at different levels to combat the effects of climate change. There is the need for a holistic and comprehensive strategy to be adopted for greater efficiency. In the case of Uyo, a comprehensive pipe-jacking drainage system holds the key to efficient and enduring solution to the problem of urban flooding. Green areas should be incorporated into future urban renewal programmes to create infiltration surfaces and reduce surface runoff. Residents should discard the habit of disposing wastes into drainage channels. If these suggestions are adopted, hopefully, the problem of flooding in Uyo will be controlled. This is important as our actions today will determine the environment we have tomorrow. By choosing to take appropriate action today, we limit the damage for tomorrow. Failure to do so may result in environmental catastrophe of monumental proportion. In the words of Francis Bacon "He that will not apply new remedies, must expect new evils, for time is the greatest innovator".

\section{REFERENCES}

Abaje, I. B., Ati, O. F and Iguisi, E. O., 2012. Recent Trends and Fluctuations in the Sudano-Sahelian Ecological Zone of Nigeria; Risks and opportunities. Journal of Sustainable Society, 1, (2): 44-51.

Abu, B., 2007. Sea level rise and the Niger Delta of Nigeria. J. of Wetland, 3, (1): 44-52. 
Adebimbe, R. U., 2011. Climate change-related disasters and vulnerability: an appraisal of the Nigerian policy environment. Environ. Research Journal, 5, (3): 97103.

Adefolalu, D. O., 2007. Climate change and economic sustainability in Nigeria. Paper presented at the International Conference on Climate Change. Nnamdi Azikiwe University, Awka, 12 14 June 2007.

Adejuwon, S. A., 2012. Global Warming and Climate Change. Climate Change Workshop, University of Ibadan Conference Centre, Ibadan, February 2012

Adesina, F. A. and Odekunle, T. O., 2011. Climate change and adaptation in Nigeria: Some background to Nigeria's response. $2011 \quad$ International conference on Environmental and Agriculture Engineering. IPCBEE, (15): 134-137.

Ayoade, J. O., 2004. Climate Change. Ibadan: Vintage Publishers, pp. 45-66.

Baudi, P. V and Ahmed, A. N., 2006. The impacts of wind related hazards in Southern Cameroon. Journal of Physical Sciences, 3, (2): 82-88.

Building Nigeria's Response to Climate Change (BNRCC)., 2008. Climate change information on Nigeria. http://www.nigeriaclimatechang e.org/ccinfo.php

Bomford, A., 2006. Slow death of Africa's Lake Chad: BBC News, Lake Chad. http://news.bbc.co.uk/2/hi/4906692.stm

Chindo, A and Nyelong, P. N., 2004. Lake Chad: From mega-lake to mini-lake. Arid Wetland Bulletin, No.6: 24-27.

Ekpenyong, R. E., 2015. An assessment of the perceived signs of climate change in Uyo Capital City, Akwa Ibom State, Nigeria. Asian Academic Research Journal of Social Science and Humanities, 1, (35): 166-181.

Ekpoh, I. J., 2009. Climate, Society and Environment. St. Paul's publishing Co. Calabar.
Ekpoh, I. J and Nsa, E., 2011. Extreme climatic variability in north-western Nigeria: an analysis of rainfall trends and patterns. Journal of Geography and Geology, 3, (1): 51-62.

Ekpoh, U. I and Ekpoh, I. J., 2011. Assessing the level of climate change awareness among secondary school teachers in Calabar, Nigeria: implication for management effectiveness. International Journal of Humanities and Social Science, 1, (3): 106-110.

Ekpoh. I. J., 2014a. Recent Severe Flooding in Calabar, Nigeria: Causes, Consequences and Possible Remedies. International Journal of Sciences, 3, (1): $102-105$.

Ekpoh, I. J., 2014b. Slow Response to Climate Change in Nigeria: need for urgent and comprehensive action. Studies in Social Sciences and Humanities, 1, (2): 19-29.

Engineering Statistics Handbook., 1995-2015. measures of Skewness and Kurtosis. http://www.itl.nist.gov/div898/handbook/ eda/section3/

Esiobu, N. S and Onubuogu, G. C., 2014. Trends, Perceptions and Adaptation Options of Livestock Farmers to Climate Change in Imo State, Nigeria: A Multinomial Logit Model Approach. Journal of Economics and Sustainable Development, 5, 19:21-36.

HUFFPOST GREEN., 2011. Mississippi River Flooding: Images of 2011 Historic Floods. http://www.huffingtonpost.com/

Ibe, A. C., 2011. Capacity building imperatives for combating climate change impacts in Nigeria's large marine ecosystem. Being a Public Lecture delivered at the University of Calabar, Calabar. University of Calabar Press.

IPCC., 2001. Climate Change 2001. Working Group 1: The Scientific Basis. Geneva, Switzerland.

IPCC., 2007. Climate Change 2007. Synthesis Report. FAR of IPCC. Geneva, Switzerland. p. 104

Mbina, A. A and Edem, E. E., 2015. Effects of Flood on infrastructural Development in 
Uyo Metropolis, Akwa Ibom State, Nigeria. Global Journal of Science Frontier Research,15, Issue 2, Version 1.0: $36-45$.

Mshelia, A. D., 2005. Adaptation strategies to climate change. Journal of Energy and Environment, 18, (3): 74-81.

Nairaland Forum 2015. Flood Takes Over Major Roads in Uyo Despite Multimillion Dollar Drainage.

http://www.latestnigeriannews.com/

Nigerican 2010. Nigeria's Climate Action Network: It's time for action. http://www.coalitions4change.org/new/in dex.php

NEST 2003. why should Nigeria be concerned about climate change? http://www.nestinteractive.org/climate_c hange.htm

NEXT 2011. Floods displace 130.000 people in Sokoto. http://234next.com/csp/cms/site $\mathrm{s} / \mathrm{Next} /$ Home/5618415-146/floods

NEWSCOM 2011. Search for Survivors Continues after Devastating US Tornado. http://www.printthis.clickability. com/

Nwafor, J. C., 2007 Global climate change. A paper presented at the International Conference on Climate Change and Economic Sustainability. Namdi Azikiwe University, Awka, Nigeria.

Odjugo, P. A. O and Ikhuoria, A. I., 2003 The impact of climate change and anthropogenic factors on desertification. Global Journal of Environmental Science, 2, (2): 118-126.

Odjugo, P. A. O., 2009. Quantifying the cost of climate change impact in Nigeria: Emphasis on wind and rainstorms. Journal of Human Ecology, 28, (2): 93101.

Odjugo, P. A. O., 2010. General overview of climate change impacts in Nigeria.
Journal of Human Ecology, 29, (1): 4755.

Oladipo, E., 2011. Towards enhancing the adaptive capacity of Nigeria: a review of the country's state of preparedness. http://www.boellnigeria.org/web/113227.html

Olorunfemi, F., 2009. Risk communication in climate change and adaptation: policy issues and challenges for Nigeria. Earth and Environmental Science, 6: 412036

Parry, M. L and Duncan, R., 1995. The Economic implications of Climate Change in Britain. Earthscan publications Ltd. London.

RADAR., 2014. The Ravaging Flood Menace in Uyo. 2, (14): Thursday, June 26.

Sumner, S., 1988. Precipitation: Process and Analysis. John Wiley and Sons, Chichester.

The Telegraph., 2013. Philippine Floods: dozens death and thousands more displaced. http://www.telegraph.co.uk/news/

THISDAY NEWS., 2013. 31 out of 36 States in Nigeria to experience devastating floods in 2013. http://www.latestnigeriannews.com/

TIME 2013. The Philippines Floods left Manila under water. http://www.time.com/

Udo-Inyang, U. C and Edem, I. D., 2012. Analysis of Rainfall Trends in Akwa lbom State, Nigeria. Journal of Environment and Earth Science, 2, (8): 60-64.

Udosen, C. E., 2012. Rainfall Trends in Uyo, Akwa Ibom State and its Implication on Urban Flooding. Journal of Engineering and Applied Sciences, 7, (1): 79-85.

Ward, T., 2009. Supporting integrated and comprehensive approaches to climate change adaptation in Africa: - Nigeria. http://www.adaptationlearning.net/ project 